Volume 9, No.1.3, 2020

International Journal of Advanced Trends in Computer Science and Engineering

Available Online at http://www.warse.org/IJATCSE/static/pdf/file/ijatcse1091.32020.pdf

https://doi.org/10.30534/ijatcse/2020/1091.32020

\title{
Developing a Community Event Sharing/ Hosting Website to Improve Quality of Life among Malaysia's Senior Citizens
}

\author{
Eugene Jenn-Ning Bong, Chien-Sing Lee \\ Sunway University, Malaysia, eugene_jennning@ @otmail.com
}

\begin{abstract}
In Malaysia, in the coming year 2020, $7.2 \%$ of the population would be 75 years of age. The problems are how should we engage seniors so that quality of life is maintained after retirement, i.e., they can still join and contribute back to society while retaining financial independence? The objectives of our project are to engage seniors actively through an integrated Web platform, JoinIt and help them to find answers to the common question of when retired, what I am supposed to do? We base our model on China, Korea and Japan, which have developed strategies to cater to their aging population and are more similar in culture. Strategies range from the Silver Age Action Initiative in China, to the Intergenerational Sympathy Project in Japan to the Seongnam Senior Complex in South Korea. Based on user requirements, we found that seniors in our case study preferred to engage with other seniors and are not so keen on intergenerational activities. Hence, we decided to enable seniors to join events, volunteer, host social activities and shop and sell products. Organizations such as Pertiwi, D'Happy Club and the Lions Club are featured. Evaluations are based on a standard user experience questionnaire and the Technology Acceptance Model. Alpha-beta testing findings reveal positive increases across all user experience attributes and technology acceptance. Most notable are overall understanding and perceived value towards the website's purposes, contents and functions, pleasantness, intention to use and surprisingly, perceived inventiveness. The top three reasons for these increases will be presented.
\end{abstract}

Keywords: Agile Methodology, Community Engagement, Contribute To Society, User Experience.

\section{INTRODUCTION}

The American Association of Retired Persons (AARP) [1], aims to: a) inspire seniors "not to be served, but to serve", b) improve the quality of life for the elderly, and c) encourage focus on dignity, independence and purpose for the elderly (AARP, [1]). Correspondingly, Foreign Policy (FP) Analytics [2], aims to highlight important issues in foreign policy, such as complex international relations and policies by understanding the various solutions pertinent to various countries. Both organizations worked together to study policies for the aged and aging in twelve countries. This results in the Aging Readiness \& Competitiveness (ARC) Report.

In Malaysia, in the year 2020, $7.2 \%$ of the population would be 75 years of age. Similar to other countries, the aging population is expected to increase over the years $[3,4,5]$. Subsequently, quality of life (QoL) and community engagement are common aspects of interest to all countries with high aging populations and correspondingly to the IEEE Smart Cities initiative.

Lee and Wong [6] have built on QoL and community engagement concerns with a proposal from a design-computational thinking approach. One of the systems, MoveIT by Lee, Guy and Chan [7], aims to encourage social engagement. Although positively received, the motivational aspects can be better improved.

These prior work considered cognitive load, and ARC's motivation theory [8], for young and old. Based on the same framework, this study extends the question of how to maintain quality of life and develop meaningful community engagement and adds on how can people especially seniors contribute back to society? We aim to develop a preliminary/ experimental Malaysian model, based on China, Japan and Korea's ARC reports. We choose these three countries due to cultural similarities (all countries are in the Asia-Pacific).

\section{RELATED WORK}

\subsection{China's active aging initiatives}

\subsubsection{Reskilling to Train Others}

According to Forbes [10], the United Nations predicts that by the year 2050, approximately $44 \%$ of the country's nation could be retirees. Consequently, China's ARC in 2003 [11] indicates that the Chinese government introduced a program called Silver Age Action. This program engages retired professionals from the industry and equips them with exposure to Western solutions. Subsequently, they volunteer in rural regions of the country. This promotes the concept of active aging with value and dignity in the society while providing a platform for the elderly to get involved in social development. 


\subsubsection{Intergenerational Engagements}

Intergenerational gatherings are best evidenced in the small province of Hangzhou, famed for its beautiful and natural West Lake. O'Neil [12] notes that people from all ages can gather at pavilions to enjoy specific activities that they are passionate about such as singing, dancing, talking, taking photos, playing musical instruments, mahjong, and board games. They can even form clubs. Many other cities have their own unique activities and attractions.

Malaysia has implemented this in residential parks. These parks are popular with dancing, taichi and walking groups. Most however, are seniors who enjoy getting to know other seniors.

\subsection{Japan's Active Aging Initiatives: Intergenerational Programs}

Japan is one of the top countries rated by the Organization for Economic Co-operation and Development (OECD) [13]. According to Japan's ARC [14], the percentage of population aged 65 or older is projected to increase to 36 percent of the total population by 2050 . This is because from 2010 through 2015, Japan's population has and is still declining.

\subsubsection{Together Old and Young (TOY)}

Tadasuke Katou, founder of Aoi Care, promoted intergenerational contacts in a special center (Schouwstra, [15]) under a program called Together Old and Young (TOY). It encourages intergenerational interactions by situating the elderly in a special residential area surrounded by schools and neighbors.

Adults from the area of all ages are encouraged to visit the center to spice up the daily activities of the elderly. This benefits both parties in terms of social being and knowledge sharing.

\subsubsection{Japan's Productivity through Intergenerational Sympathy Project}

The Research on Productivity through Intergenerational Sympathy Project (Yasunaga, Murayama, Takahashi, Ohba, Suzuki, Nonaka, Kuraoka, Sakurai, Nishi, Sakuma, Kobayashi, Shinkai, and Fujiwara, [16]) encourages the elderly to read story books to children in elementary schools. While reading, they can share their cultural knowledge and life experiences. Benefits are obvious: building intergenerational relationships towards better psychological heath in the long run.

\subsection{Korea's active aging initiatives:}

Korea's ARC [17] indicates that in 2017, Korea would have exceeded the UN threshold of for an aged society, i.e., 14 percent of its population over age 65. Surprisingly, it has taken only 18 years to transition from an "aging" society, faster than many current "aged society."

\subsection{1 'HAPI' Life Model}

Kim [18] highlights that Korea's 'HAPI' life model emphasizes the elderlies want to be respected by others. Initiatives such as 'Gangnam Senior Plaza' attracts volunteers and organizations to host events to gather people from all ages and background to address issues encountered by the elderly. The 'HAPI' life model is well-received by the seniors of Korea. Kim [18] further highlights that seniors are encouraged to volunteer to make full use of their talent and experience to aid and enhance the senior's program in Korea.

\subsubsection{Preparing and Training the Young for a Rapid Aging Population}

According to the National Public Radio (NPR), $40 \%$ of the people in Korea will be 65 years old or even older by the middle of the century. As such, Kuhn [19] finds that Korea's ARC emphasizes on preparing and training the young for a rapidly aging population, besides helping the old.

The Seongnam Senior Complex located in Seoul, hosts activities for young people to experience what the elderly would feel. Empathy can help the younger generation to have more sympathy for the elderly. Some instances [19] involve:

a) a young person impersonating an elderly who is bedridden;

b) wearing sandbags to create a weighting-down effect on students' limbs, recreating the feeling experienced by the elderly forcing the students to stoop,

c) wearing 3D glasses to mimic dementia effects.

\subsubsection{Social Isolation and Having No Purpose for Living}

Korea's ARC [17] recognizes the risk of social isolation and having no or little purpose for living, which can lead to suicidal tendencies. Thus, the Korean government launched the "Promotion of Culture that Respects Lives," in cooperation with the Ministry of Health and Welfare and the Korean media itself. Other anti-suicidal psychological programs aim to ensure social involvement and mental health. For example, the "Special Elderly Volunteer Program" matches volunteer organizations that are looking for specific skill sets with seniors who retire.

In the next section, we present the methodology.

\section{METHODOLOGY}

\subsection{Model Development and Refinement}

The above three models are the bases for our Malaysian model, which is then refined through user requirements gathering and subsequent user testings. 


\subsection{Software Development Lifecycle (SDLC) and Agile Methodology}

The SDLC provides guidelines for analysis, design, development, evaluation and implementation. It is a standard for all information systems development prior to user acceptance testing (Covalent Marketing, [20]). The approach adopted is agile methodology.

Agile methodology encourages incremental non-linear development and adaptations based on user feedback. It enables better user understanding, creates flexibility and easier detection of bugs.

\subsection{Evaluation Tools}

We used two evaluation tools, both in the form of questionnaires. The first evaluation tool, the Technology Acceptance model and second, the User Experience Questionnaire (UEQ) measurement tool. Technology Acceptance Model [21] is a standard measurement tool for all information systems. Two crucial factors leading to technology acceptance are perceived usefulness and perceived ease of use.

The User Experience Questionnaire (UEQ) measurement tool by Schrepp, Thomaschewski and Hinderks [22-24] aids identification of the user's expectations, feelings, attitudes and impression when using a particular product. UEQ consists of 26 items on a scale of one to six. The questionnaire is posted online and in hardcopy (user's preference).

\section{MODEL DEVELOPMENT AND REFINEMENT}

\subsection{Model Development}

The objectives of the system to be designed and developed is to provide more opportunities for socio-cognitive involvements/engagements. This system needs to cater to both young and old, volunteers, non-profit organizations and corporate organizations. Hence, the website to be developed is a community website.

Based on China, Japan and Korea's models, we developed a proposed Malaysian model (Table 1).
Table 1: Our model for a healthy aging society

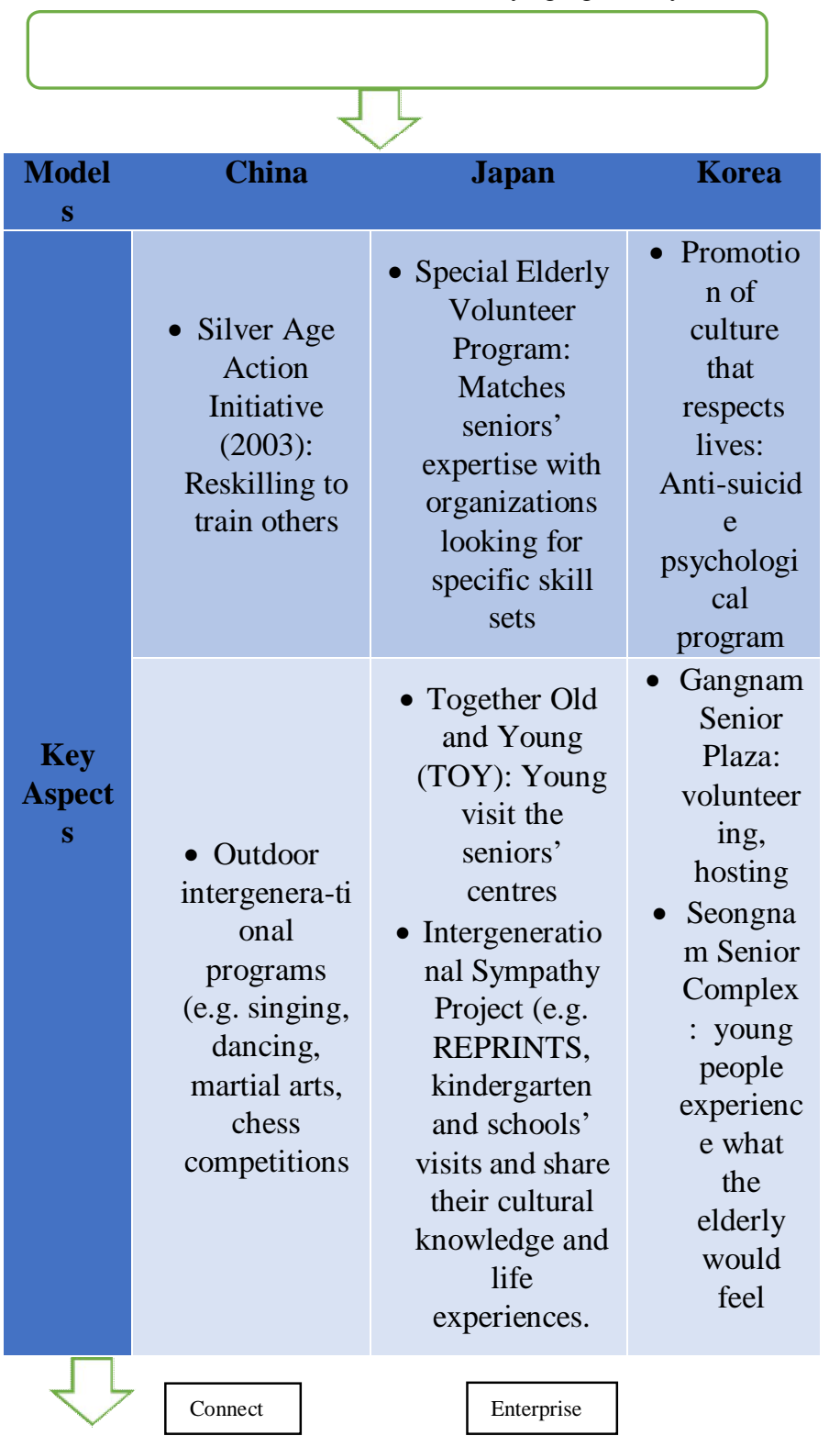

\begin{tabular}{c|c|c|}
$\begin{array}{c}\text { Our } \\
\text { intergenerational } \\
\text { website }\end{array}$ & \multicolumn{1}{c}{ Internal } & \multicolumn{1}{c|}{ External } \\
\hline $\begin{array}{c}\text { Community } \\
\text { engagement, } \\
\text { Intergenerational } \\
\text { engagement }\end{array}$ & $\begin{array}{c}\text { JoinIT portal's } \\
\text { members }\end{array}$ & $\begin{array}{c}\text { Website Club names } \\
\text { (i.e. Pertiwi, Rotary } \\
\text { Club, D'Happy Club } \\
\text { and Lions Club) }\end{array}$ \\
\hline $\begin{array}{c}\text { Group activities } \\
\text { of similar } \\
\text { interests }\end{array}$ & $\begin{array}{c}\text { Host/Join/ } \\
\text { Organize/ } \\
\text { Volunteer }\end{array}$ & $\begin{array}{c}\text { Host/Join/ Organize/ } \\
\text { Volunteer (special/ } \\
\text { professional Skills) }\end{array}$ \\
\hline $\begin{array}{c}\text { Entrepreneurial } \\
\text { activities }\end{array}$ & $\begin{array}{c}\text { Buy and sell to } \\
\text { internal } \\
\text { members }\end{array}$ & $\begin{array}{c}\text { Buy and sell to } \\
\text { external parties }\end{array}$ \\
\hline
\end{tabular}




\subsection{Model Refinement}

\subsubsection{Sample}

According to Jabatan Perkhidmatan Awam (General Services Department) and the pension department, the National Policy considers a person as a senior citizen if she/he is above sixty years of age. Furthermore, from 65 to 74 years of age, seniors are considered "Young-Old", while from the age of 75 to 84 "Old-Old" and 85 and above "Very Old-Old" [4]. For our study, we target seniors in the Young-Old category.

For user requirements, a sample size of 30 is collected. For alpha testing, the distribution of participants are 65 to 74 years old) at $36 \%$ and 50 to 65 years old $(42 \%)$. The remaining 22 percent are frequent website users from the younger generation, interested in finding "quirks" in the website.

$64 \%$ of the respondents are female. $38 \%$ of the respondents are from contractors, project manager, clerks, administrative and architects from the construction industry, 20\% are students, teachers, early childhood educator and lecturer. Others are housewives, self-employed, chef, promoter and transporters.

For beta testing, the distribution of participants are almost the same. There is also an increase of 6 to $11.4 \%$ for in the category of frequent web users who are young aduts.

$53.8 \%$ of the respondents are female. $31.8 \%$ are from the construction background. There is an increase of $26.9 \%$ from the education background. Hence, the distributions are almost similar as that of alpha testing.

\subsubsection{Data Collection}

Three rounds of data collection are carried out:

a) for user requirements, the location is a community center called the Subang Jaya Municipal Sports Complex. The location is chosen because it is frequented by various races, and ages.

b) for alpha testing, the location is an open air community carnival hosted by a popular seniors' club in conjunction with its 10th Anniversary.

c) for beta testing, retirees from the construction and early childhood education sectors form the majority of the respondents. A minor percentage of respondents are university students.

Being anonymous, a paper code is included at the top right of the questionnaire, to ensure no duplication when keying in inputs from hard to soft copy on Google Form.

\subsubsection{User Requirements}

Some interesting findings from user requirements gathering are:

a) Respondents who are educators accept intergenerational programs with open arms but respondents from other categories of occupation are not as keen.

b) None of the participants indicate interest to host or organize any intergenerational program. They would prefer to engage with people of their own age. Furthermore, volunteer programs for instance by the Subang Jaya (USJ) North Rotary Club, Malaysia have already opened opportunities for volunteering and working together with the younger generation in terms of education and healthcare.

Based on this difference from the expectations in our model, the intergenerational component in our system, JoinIt, is not developed. Instead, we link to clubs and associations such as Pertiwi, Rotary Club and Lions Club.

Some seniors also expressed interest in selling cakes and other products. We acknowledge initiatives by the Malaysian government, especially $\mathrm{MDeC}$, which precedes this initiative, in empowering common folks with entrepreneurial knowledge and skills, the key ecosystem. As such, we hope to complement such initiatives.

\subsection{System Description}

The use case for the system is presented in Fig. 1. Two screenshots from the website are presented in Figs. $2 a$ and $2 b$.

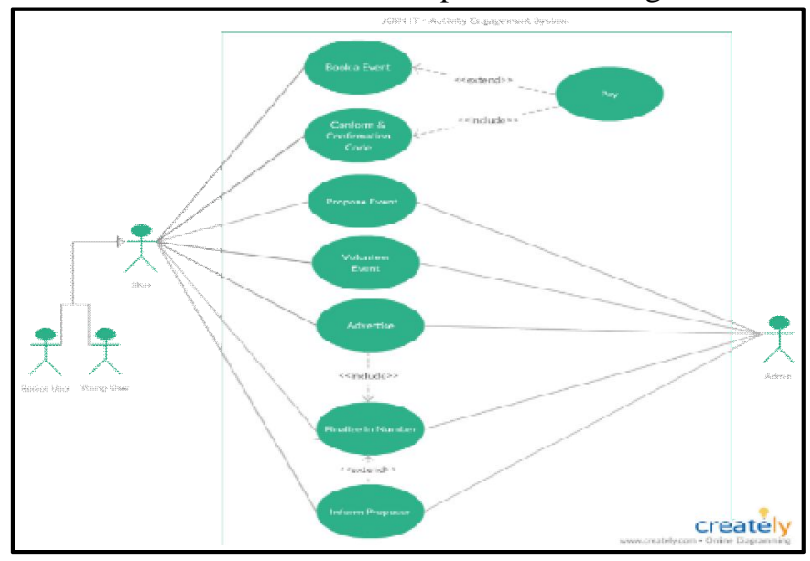

Figure 1: Use Case

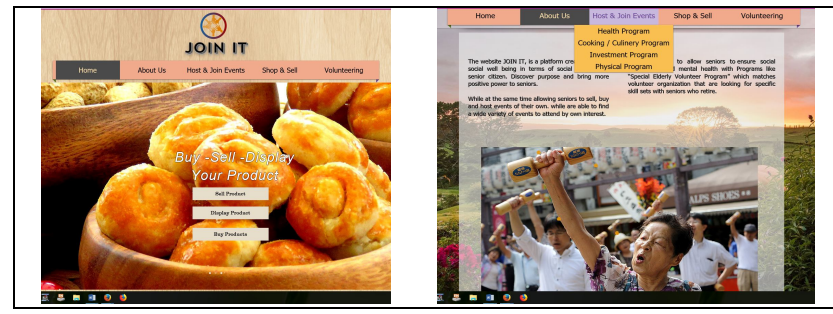

Figures 2a, b: Screenshots of the System 


\section{USER TESTINGAND DISCUSSION}

\subsection{Alpha-Testing Findings}

The alpha testing findings such as in Table 1 below indicated that the design of user interfaces greatly influences perceived ease of use and perceived usefulness. Color contrast and differentiating between website text and instructions for the health, cooking, investment and physical programs turn out to be critical in increasing clarity.

The term "easy to learn" in the survey points to unambiguous and interaction of participants towards the website content and features. $86 \%$ of the users provide a score of 5 and above (Figure 3a). A healthy $40 \%$ of users indicate the ease of use is nearly perfect.

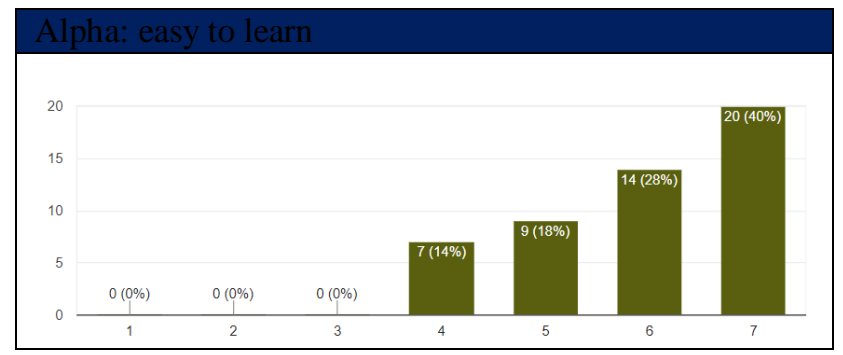

Figure 3a:How Easy to Learn

The term "clear and confusing" in the questionnaire points to the cognitive demand due to the website contents and functions. All ratings are at least on or above the average rating from 4 to 7 (Fig. 3b).

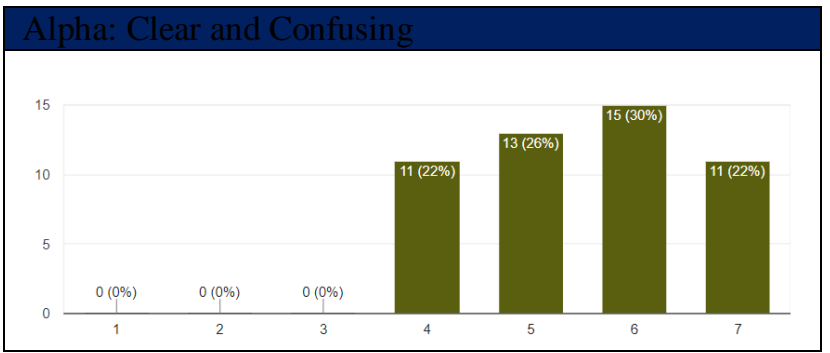

Figure 3b: How Clear or Confusing

The term "organized" in the questionnaire points to the orderly layout of the website contents. The rating of 4 and 5 (Fig. 3c) is mainly due to some unorganized buttons and navigation bar that are not proportionate and are partially not clear on the mobile phone.

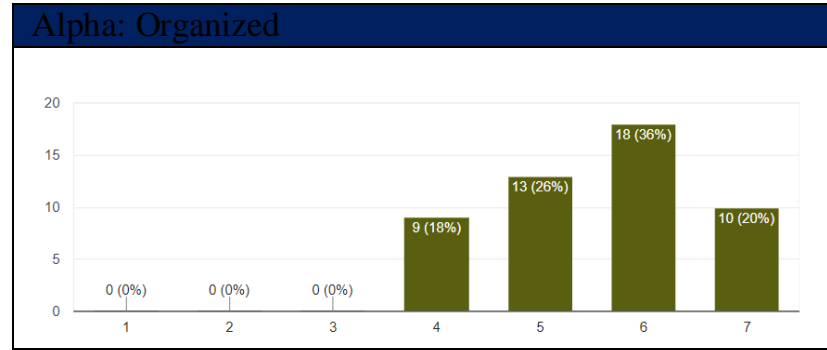

Figure 3c: How Organized

With regards to intention to use, $24 \%$ of the respondents are not keen (Fig. 3d). This came mostly from the young adults, as their intention is mostly to find "quirks."

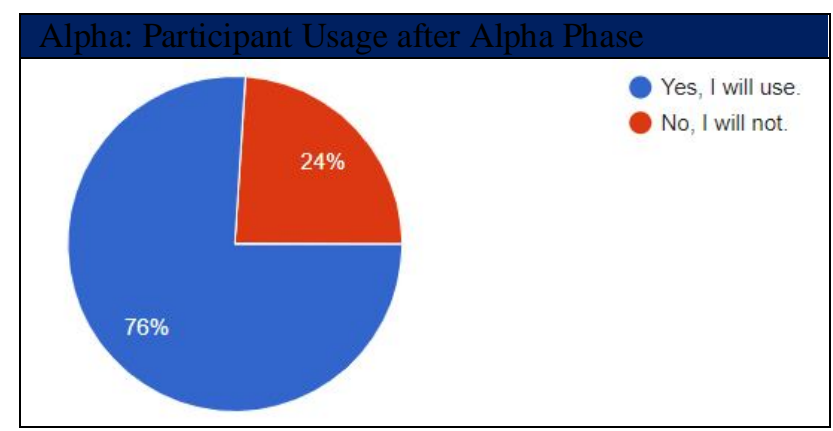

Figure 3d:Future Intention to Use

The respondents very kindly suggested some improvements (Table 2).

Table 2: User Suggestions from Alpha Testing (UI)

\begin{tabular}{|l|l|}
\hline \multicolumn{1}{|c|}{ Current (Alpha) } & \multicolumn{1}{c|}{ Enhancement of Alpha } \\
\hline 1. Unclear texts & 1. Text change \\
\hline $\begin{array}{l}\text { 2. Desktop website } \\
\text { form view }\end{array}$ & $\begin{array}{l}\text { 2. Mobile form layout } \\
\text { adjustments }\end{array}$ \\
$\begin{array}{l}\text { 3. Text in input box } \\
\text { (with sample text) }\end{array}$ & $\begin{array}{l}\text { 3. Text in input box } \\
\text { (automatically added) }\end{array}$ \\
\hline $\begin{array}{l}\text { 4.Wallpaper } \\
\text { changes }\end{array}$ & needs Wallpaper changed \\
\hline
\end{tabular}

Ease of use has improved and one feature added: to sell health products at a page categorized separately from the regular product display pages.

\subsection{Beta Testing Findings}

The outcome in the beta testing indicates a noticeable increase of $31.2 \%$ who rated 7 (Fig. 4a) for how easy it is to learn. Also, new participants are frequent users. 


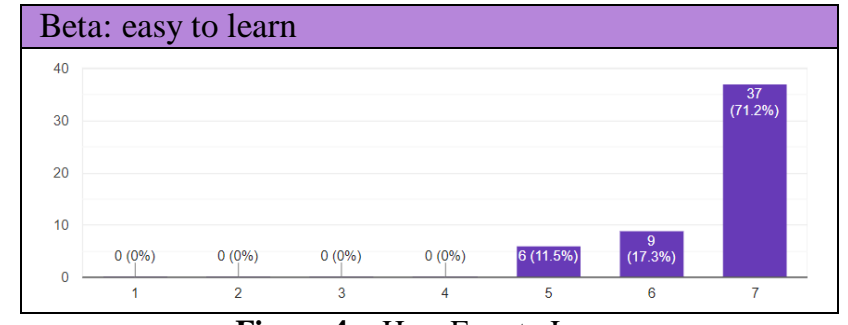

Figure 4a: How Easy to Learn

With an increase of 37.6 percent for rating 7 for clarity, the website looks very promising (Fig. 4b).

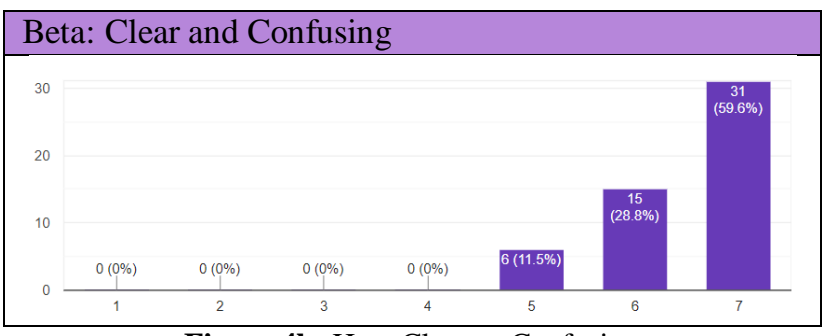

Figure 4b: How Clear or Confusing

With an increase of 55\% rating 7 (Fig. 4c) for how organized the website is, respondents are happy with the changes made towards the layout and graphics at the website based on feedback obtained.

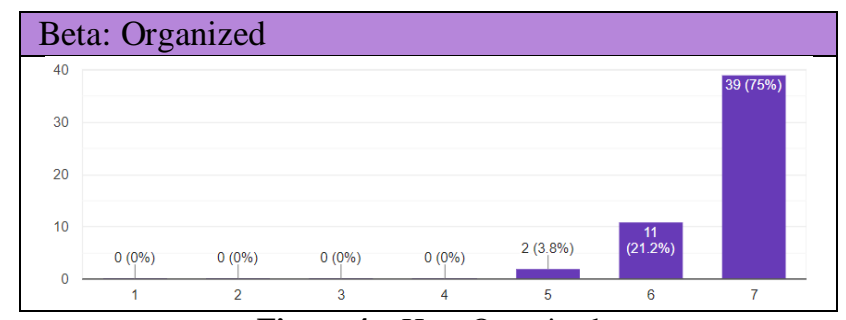

Figure 4c: How Organized

The number of respondents who decided that they would use the system after the beta survey increased by $12.5 \%$, thanks to the feedback obtained (Fig. 4d).

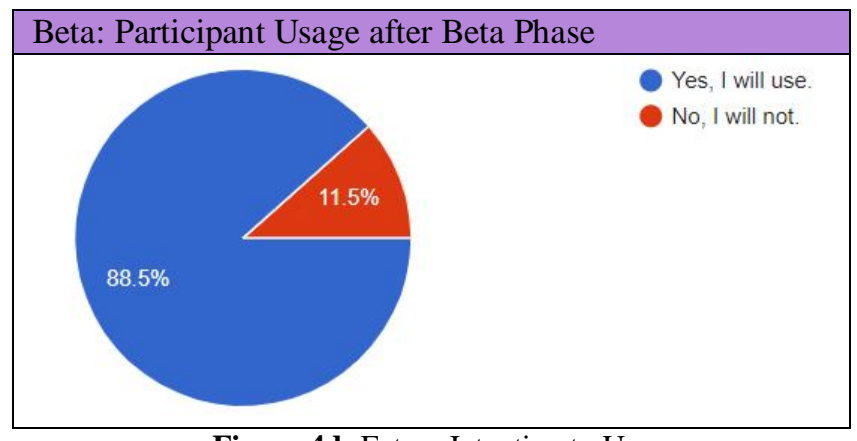

Figure 4d: Future Intention to Use

\section{SIGNIFICANCE}

Significance lies in:

a) A The Malaysian Healthy Aging Society [24] aims to promote integrative approaches towards the ageing process and to foster and co-ordinate education, study and research in ageing in Malaysia. We hope to contribute towards an integrated platform for community engagement involving various stakeholders.

b) Design factors for socio-cognitive-community engagement, which may complement existing ecosystems.

\section{CONCLUSION}

The proposed Malaysian model is derived from key aspects of models in China, Japan and Korea, refined by user requirements gathering and user testing. Hopefully, with greater awareness of such models, we can be more ready to empower Malaysians to age healthily in society, towards a better quality of life as defined by the ARC and OECD.

\section{ACKNOWLEDGEMENT}

This research is partially supported by the Malaysian Fundamental Research Grant Scheme (FRGS) ref. FRGS/2016/ICT04/SYUC/01/1 with ethics approval SUREC 2016/067. The authors fully acknowledge the Ministry of (Higher) Education (MOHE) for the approved fund and Sunway University for support.

\section{REFERENCES}

1. AARP. (2018). AARP's Mission, Vision, Advocacy, Community Service \& Products. [online] Available at: https://www.aarp.org/about-aarp/?intcmp=AE-HP-FTRABOUT [Accessed 13 Sep. 2018].

2. Fpgroup.foreignpolicy.com. 2018. Our History Foreign Policy Group. [online] Available at: https://fpgroup.foreignpolicy.com/about/history/ [Accessed 13 Sep. 2018].

3. Mafauzy, M. 2000. The Problems and Challenges of the Aging Population of Malaysia. [online] PubMed Central. Available https://www.ncbi.nlm.nih.gov/pmc/articles/PMC340620 9/ [Accessed 17 Jun. 2018].

4. Wan Ibrahim, W., Mohamad Ashi, S., Othman, N., Zukri, S., Anwar, R., Miskiman, N., Daud, S. and Abdul Shukor, F. 2017. Population and Demographics. [online] Dosm.gov.my. Available at: https://www.dosm.gov.my/v1/uploads/files/6_Newslette r/Ageing.pdf [Accessed 17 Jun. 2018].

5. Jpapencen.gov.my. 2005. Jabatan Perkhidmatan Awam, Malaysia's Official Portal Bahagian Pasca Perkhidmatan. [online] Available at: 
http://www.jpapencen.gov.my/english/senior_citizen.hm 1 [Accessed 19 Jun. 2018].

6. Lee, C. S. and Wong, K. D. 2017. Developing Community-based Engagement in Smart Cities: A Design-Computational Thinking Approach. International Conference on Industrial Engineering and Engineering Management, December 10-13, 2017, Singapore, 832 836.

https://doi.org/10.1109/IEEM.2017.8290008

7. Lee, C. S., Guy, S. Y., and Chan, S. W. L. 2018. Towards Personalized Cognitive-Social-Affective Engagement Among Active Seniors: A Case Study on UX and Inclusive Design. Workshop on Playfulness in teaching-learning STEAM, International Conference on Computers in Education, November 26-30, 2018, Manila, Philippines.

8. Keller, J. M. (2010). Motivational Design for Learning and Performance: The ARCS Model Approach. New York: Springer. https://doi.org/10.1007/978-1-4419-1250-3

9. Rapoza, K. 2017. China's Aging Population Becoming More of A Problem. [online] Forbes.com. Available at: https://www.forbes.com/sites/kenrapoza/2017/02/21/chi nas-aging-population-becoming-more-of-a-problem/\#50 b586c8140f [Accessed 17 Jun. 2018].

10. Arc.aarpinternational.org. 2014. The Aging Readiness \& Competitiveness Report China. [online] Available at: http://arc.aarpinternational.org/countries/china [Accessed 17 Jun. 2018].

11. O'Neill, P. 2018. Intergenerational Gatherings Among the Water and Willows (Intergenerational Program). [online] Penn State University. Available at: https://aese.psu.edu/extension/intergenerational/articles/i ntergenerational-contact-zones/recreation-china

[Accessed 17 Jun. 2018].

12. Oecdbetterlifeindex.org. 2018. OECD Better Life Index. [online] Available at:

http://www.oecdbetterlifeindex.org/countries/japan/ [Accessed 5 May 2018].

13. Arc.aarpinternational.org. 2017. The Aging Readiness \& Competitiveness Report Japan. [online] Available at: http://arc.aarpinternational.org/countries/japan [Accessed 17 Jun. 2018].

14. Schouwstra, J. 2017. Innovative intergenerational care in Fujisawa, Japan. [online] ToyProject.net. Available at: http://www.toyproject.net/2017/04/innovative-intergener ational-care-in-fujisawa-japan/ [Accessed 17 Jun. 2018].

15. Yasunaga, M., Murayama, Y., Takahashi, T., Ohba, H., Suzuki, H., Nonaka, K., Kuraoka, M., Sakurai, R., Nishi, M., Sakuma, N., Kobayashi, E., Shinkai, S. and Fujiwara, Y. 2016. Multiple impacts of an intergenerational program in Japan: Evidence from the Research on Productivity through Intergenerational Sympathy Project. [online] Available at:

https://onlinelibrary.wiley.com/doi/pdf/10.1111/ggi.127 70 [Accessed 17 Jun. 2018].

https://doi.org/10.1111/ggi.12770

16. Arc.aarpinternational.org. 2017. The Aging Readiness \& Competitiveness Report Korea. [online] Available at: http://arc.aarpinternational.org/countries/korea [Accessed 17 Jun. 2018].

17. Kim, J. 2018. 'HAPI' life model for the new older generation in Korea. [online] Wiley Online Library. Available at:

https://doi-org.ezproxy.lancs.ac.uk/10.1111/ajag.12082 [Accessed 17 Jun. 2018].

18. Kuhn, A. 2013. NPR Choice page. [online] National Public Radio (NPR). Available at: https://www.npr.org/2013/01/04/168615553/south-korea -prepares-the-young-for-a-rapidly-aging-population [Accessed 17 Jun. 2018].

19. Covalent Marketing. 2015. Software Development Lifecycle: Waterfall vs. Agile - Covalent Marketing. [online] Available at: http://www.covalentmarketing.com/blog/2015/10/19/sof tware-development-lifecycle-waterfall-vs-agile-2/ [Accessed 19 Jun. 2018].

20. Venkatesh, V., and Davis, F.D. 2000. A theoretical extension of the technology acceptance model: Four longitudinal field studies. Management Science, 46(2), 186-204. https://doi.org/10.1287/mnsc.46.2.186.11926

21. Schrepp, M., Thomaschewski, J. and Hinderks, A. 2017. Design and Evaluation of a Short Version of the User Experience Questionnaire (UEQ-S). [online] Available at: https://www.researchgate.net/publication/319863058_D esign_and_Evaluation_of_a_Short_Version_of_the_Use r_Experience_Questionnaire_UEQ-S [Accessed 20 Jun. 2018]. https://doi.org/10.9781/ijimai.2017.09.001

22. Ohd.moh.gov.my. 2016. Pelan Strategik Technnologi Maklumat Kementrian Kesihatan Malaysia (2016 2020). [online] Available at: http://www.moh.gov.my/penerbitan/buku\%20PSTM\%2 0KKM\%202016\%202020.pdf [Accessed 13 Sep. 2018].

23. Malaysia Healthy Ageing Society. 2017. Home Page Malaysian Healthy Ageing Society. [online] Available at: http://healthyageing.org/ [Accessed 17 Jun. 2018].

24. Cesar A. Llorente, Jefferson O. Ang, , Kenneth Robert O. Chan Shio, John Eric O. Chua, Elijah Ivin C. $\mathrm{Cu}$. Implementation of a Web based Weather Monitoring Station and Data Storage System. International Journal of Advanced Trends in Computer Science and Engineering. Volume 8, No.3, May - June 2019 https://doi.org/10.30534/ijatcse/2019/29832019 